\title{
Knowledge, attitude and practices on cervical cancer screening among undergraduate female students in University of Gondar, Northwest Ethiopia: an institution based cross sectional study
}

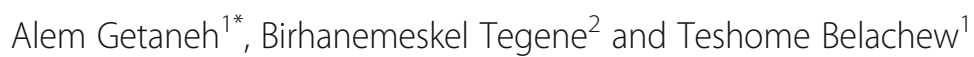

\begin{abstract}
Background: Cervical cancer is a major public health problem. In the world, cervical cancer is the fourth most common cancer among women and it is one of the leading causes of cancer mortality in females. It is the second most common women cancer in Ethiopia with almost 6300 new cases and 4884 deaths annually. Despite the high burden of new cases and deaths, there is a scarcity of data on knowledge, attitude and practices (KAP) towards cervical cancer screening among female university students in Ethiopia particularly in the study area. Therefore, the present study was aimed to assess the KAP of undergraduate female students towards cervical cancer screening.

Methods: An institution based cross-sectional study was conducted in April 2018 at the University of Gondar, College of Medicine and Health Sciences undergraduate female students. Pretested, self-administered questionnaire was used for data collection. Four hundred and three female students were recruited by a simple random sampling method and the data were entered and analyzed using SPSS version 20 statistical packages. Descriptive data analysis was used to report the results.

Results: More than half of the respondents (59.3.3\%) had good knowledge, whereas nearly $67.7 \%$ of the respondents had favorable attitude towards cervical cancer. However, less than $1 \%$ of the respondents had been screened for cervical cancer.

Conclusion: Although undergraduate female students had apparently good knowledge and favorable attitude, their practices on cervical cancer screening were quite low. Therefore, the health sectors and the gender streaming office of the university mobilize students to strengthen the uptake the cervical cancer screening practice.
\end{abstract}

Keywords: KAP, Cervical cancer, Undergraduate female university students, Ethiopia

\footnotetext{
* Correspondence: alemgetaneh2@gmail.com

'Department of Medical Microbiology, School of Biomedical and Laboratory Science, College of Medicine and Health Sciences, University of Gondar, 196 Gondar, Ethiopia

Full list of author information is available at the end of the article
}

C C The Author(s). 2021 Open Access This article is licensed under a Creative Commons Attribution 4.0 International License, which permits use, sharing, adaptation, distribution and reproduction in any medium or format, as long as you give appropriate credit to the original author(s) and the source, provide a link to the Creative Commons licence, and indicate if changes were made. The images or other third party material in this article are included in the article's Creative Commons licence, unless indicated otherwise in a credit line to the material. If material is not included in the article's Creative Commons licence and your intended use is not permitted by statutory regulation or exceeds the permitted use, you will need to obtain permission directly from the copyright holder. To view a copy of this licence, visit http://creativecommons.org/licenses/by/4.0/. The Creative Commons Public Domain Dedication waiver (http://creativecommons.org/publicdomain/zero/1.0/) applies to the data made available in this article, unless otherwise stated in a credit line to the data. 


\section{Background}

Cervical cancer is cancer of uterine cervix that causes a serious public health problem [1]. It is a major cause of morbidity and mortality among women's in the world [2]. The main cause for cervical cancer is the Human Papilloma Virus (HPV) which is transmitted through sexual intercourse. Human Papilloma Virus is a group of viruses that commonly infect the reproductive tract of sexually active young adult men and women, Today, more than 150 different HPV types have been identified, Particularly the age of 22-25 years [3]. Among these, thirteen HPV types such as HPV16, 18, 31, 33, 35, 39, $45,51,52,56,58,59$, and 68 are identified as "high risk HPV" (HR-HPV) due to their relatively high carcinogenic potential leading to the development of cervical cancer among more than $150 \mathrm{HPV}$ strains being found [4]. HPV types 16 and 18 are responsible for about $70 \%$ of all cervical cancer cases worldwide. Human Papilloma Virus vaccines that prevent HPV 16 and 18 infections are now available and have the potential to reduce the incidence of cervical and other anogenital cancers [5]. Early-onset of sexual activities, multiple sexual partners, extended use of oral contraceptives, immunesuppression and smoking are other known risk factors [6].

Malignant cervical cancer is characterized by vaginal bleeding between menstrual periods, pelvic pain, vaginal bleeding during/after sexual intercourse and vaginal secretion. However, it is one of the most easily preventable forms of female cancer. A key aspect of its prevention is the identification of the premalignant form by cervical screening [7-9] and HPV vaccination [2]. However, there are so many reasons mentioned as barriers towards cervical cancer screening in developing countries such shortage and underutilization of screening facilities, lack of awareness and poor attitude towards cervical cancer and risk factors, beliefs about cervical cancer, feeling healthy, stigma, fear of the test results and fear of marital disturbance $[10,11]$.

Cervical cancer is the fourth most common cancer among women worldwide, ranking after breast cancer, colorectal cancer and lung cancer. Approximately 570, 000 cases of cervical cancer and 311, 000 deaths from the disease occurred in 2018 . More than $85 \%$ of the estimated deaths occur in low and middle income countries $[11,12]$. Cervical cancer is the second most common cancer after breast cancer among women in the developing world and is responsible for the deaths of 230,200 and the new cases of 444,500 annually [13] The rate of cervical cancer was five times higher in developing countries (25 per 100,000) compared with more developed countries (5 per 100,000 ) [14].

In Ethiopia, cervical cancer is the second most common cancer and the second most deadly cancer among
Ethiopian women with almost 6300 new cases and 4884 deaths annually [15].

Despite the growing number of cervical cancer cases in Ethiopia, there is still a gap in knowledge, attitude and practice towards cervical cancer screening. No previous study was done on the KAP towards cervical cancer and its screening among the University of Gondar, College of Medicine, and Health Sciences undergraduate female students. Therefore, the present study was aimed to assess their baseline KAP towards cervical cancer and its screening.

\section{Methods \\ Study area}

The study was conducted at the University of Gondar, College of Medicine and Health Sciences in Gondar town, northwest Ethiopia. Gondar town is located in

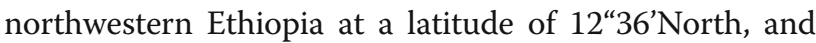
longitude of 37"28'East. The University of Gondar is located in the west of the Central Gondar Administrative Zone, which is, $747 \mathrm{~km}$ far from Addis Ababa in the Northwest direction [16]. According to the central and statistical agency of Ethiopia report in 2015, the town has 12 sub city, 22 urban and 11 rural kebeles with a total projected population of 323,900 . In the town; there is one university which has 5 campuses. Of these College of Medicine and Health Sciences is the one that provides a service for more than 5400 students every year. The college has one institution, 5 schools and 12 departments. In the year 2018, the total number of female students was 1746.

\section{Study design and period}

An institution-based cross-sectional study was conducted at the University of Gondar, College of Medicine, and Health Sciences on April 2018.

\section{Population \\ Source population}

All female students in College of Medicine and Health Sciences were used as sources of population.

\section{Study population}

All selected regular undergraduate female students in College of Medicine and Health Sciences were used as a study population.

\section{Eligibility criteria}

All regular Medicine and Health Sciences under graduate female students were included in the study. 


\section{Operational definition \\ Knowledge}

Participants who have scored greater than or equal to 6 correct answers from 11 knowledge questions were considered to have good knowledge, and those who had scored less than 6 answers were considered to have poor knowledge.

\section{Attitude}

Participants who have scored greater than or equal to 5 correct response from 9 attitude questions were considered to have a favorable attitude and those who had scored less than 5 were considered to have unfavorable attitude.

\section{Screening practice}

Participants who are screened for cervical cancer at least once.

\section{Sample size determination}

The required sample size was determined by using the single population proportion formula based on the following assumptions. The proportion of knowledge/attitude was taken from the results of a study done in Mizan Tepi University, Ethiopia, 61\% [17], with 95\% CI, $\alpha$-level $5 \%$, and considered the margin of error $5 \%$. The minimum sample size was calculated based on the following formula:

$$
\begin{aligned}
\mathrm{n} & =(\mathrm{Za} / 2)^{2} \mathrm{P}(1-\mathrm{P}) / \mathrm{d}^{2} ; \mathrm{n} \\
& =(1.96)^{2} * 0.61(1-0.61) /(0.05)^{2}=367
\end{aligned}
$$

Where: $\mathrm{n}=$ sample size.

$\mathrm{Z} \alpha / /_{2}=$ normal distribution value at 95\% CI $(\mathrm{Z}=1.96)$.

$\mathrm{P}=$ the successful proportion of knowledge/attitude (0.61).

$\mathrm{d}=$ margin of error $(5 \%)$.

Therefore, the final sample size after adding $10 \%$ nonresponse rate was 403 female students.

\section{Sampling technique}

The study population was stratified based on the department of their discipline. Participants were selected from 12 departments of the University of Gondar, College of Medicine and Health Sciences by using simple random sampling technique. The sample size was proportionally allocated for each department based on their class size by using the formula: $\mathrm{ni}=\mathrm{n}^{*} \mathrm{Ni} / \mathrm{N}$.

Where $\mathrm{n}=$ the total sample size (403); $\mathrm{ni}=$ required sample size in each department, $\mathrm{Ni}=$ Number of female students in each department; $\mathrm{N}=$ Total number of female students in the study area (1746).

\section{Data collection}

The data was collected by using a self-administrated questionnaire that contains different items like sociodemographics, knowledge, and attitude and practice questions towards cervical cancer screening. Questionnaires were adapted from different pieces of literature from previous studies $[17,18]$. These questions explored the respondent's knowledge, attitude, and practices about cervical cancer screening. The questionnaires were translated from English to Amharic for data collection and vice-versa for data entry for ensuring its consistency.

\section{Data quality management}

A pre-test was done on $5 \%$ of the questionnaire to make sure the questionnaire was appropriately structured and to ensure its consistency. Two days of training were given to data collection facilitators for improving the data collection process. Close supervision was done by the principal investigator for ensuring the completeness of questionnaires at the time of data collection. Finally, data editing and clearance were done for the proper management of data.

\section{Data management and analysis}

Data were entered after encoded the completed questionnaires and analyzed using SPSS version 20 statistical packages. Descriptive data analysis was used to describe the knowledge, attitude, and practices for cervical cancer screening. The results were presented in mean, standard deviation, texts and tables.

\section{Results}

Socio-demographic characteristics of participants

A total of 403 undergraduate female health science students were included in this study. The overall response rate was $100 \%$. The minimum age of the study participants was18 and the maximum age was 25 with the mean $( \pm S D)$ age of $21( \pm 1.5)$ years. Among these, the majority 217 (54\%) of the respondents were between the age range 21-25 years while the remaining 186 (46\%) were between the age range 18-20 years. About $322(79.9 \%)$ of the respondents were orthodox Christian and 256(63.5\%) were Amhara in ethnicity. Regarding marital status, $390(96.8 \%)$ of the respondents were single followed by $11(2.7 \%)$ married, $1(0.2 \%)$ divorced, and 1 (0.2\%) separated. About 333 (82.6\%) of the respondents, came from urban parts of Ethiopia.

\section{Knowledge of the respondents towards cervical cancer}

From this study, more than half of the respondents, 239 (59.3\%) had good knowledge, whereas the remaining two-fifth 164(40.7\%) of respondents characterized by poor knowledge. The majority 363 (90\%) of the 
Table 1 Knowledge towards cervical cancer and its screening at the University of Gondar, Ethiopia, April, 2018 ( $n=403)$

\begin{tabular}{|c|c|c|c|}
\hline Variables & Categories & Number & Percent (\%) \\
\hline \multirow[t]{2}{*}{ Have you ever heard about cervical cancer? } & Yes & 363 & 90.1 \\
\hline & No & 40 & 9.9 \\
\hline \multirow[t]{5}{*}{ Where did you learn about cervical cancer? } & Teachers & 119 & 32.8 \\
\hline & News media & 108 & 29.8 \\
\hline & Health institutions & 98 & 27 \\
\hline & Family, friends, neighbors & 30 & 8.3 \\
\hline & Magazine & 8 & 2.2 \\
\hline \multirow[t]{5}{*}{ What is causative agent of cervical cancer? } & Virus & 142 & 35.2 \\
\hline & Bacteria & 54 & 13.4 \\
\hline & Fungi & 20 & 5 \\
\hline & Parasite & 16 & 4 \\
\hline & Don't know & 171 & 42.4 \\
\hline \multirow[t]{5}{*}{ What are the symptoms of carcinoma of the cervix? } & Vaginal foul smelling discharge & 84 & 20.8 \\
\hline & Vaginal irregular bleeding & 83 & 20.6 \\
\hline & Post coital bleeding & 15 & 3.7 \\
\hline & All of the three symptoms & 29 & 7.2 \\
\hline & Don't know & 192 & 47.6 \\
\hline \multirow{6}{*}{$\begin{array}{l}\text { Do you know the } \\
\text { Risk factors for cancer of the cervix? }\end{array}$} & Having multiple sexual partners & 101 & 25.1 \\
\hline & Human papilloma virus & 63 & 15.6 \\
\hline & Early sexual intercourse & 48 & 11.9 \\
\hline & Cigarette smoking & 11 & 2.7 \\
\hline & All the four risks & 47 & 11.7 \\
\hline & Don't know & 133 & 33 \\
\hline \multirow[t]{6}{*}{ How can a person prevent getting cancer of the cervix? } & Avoid multiple sexual partners & 101 & 25.1 \\
\hline & Avoid early sexual intercourse & 68 & 16.9 \\
\hline & HPV vaccination & 33 & 8.2 \\
\hline & Quit cigarette smoking & 19 & 4.7 \\
\hline & All the four prevention mechanisms & 42 & 10.4 \\
\hline & Don't know & 140 & 34.7 \\
\hline \multirow[t]{3}{*}{ Can cancer of the cervix be cured in its earliest stages? } & Yes & 296 & 73.4 \\
\hline & No & 19 & 4.7 \\
\hline & Don't know & 88 & 21.8 \\
\hline \multirow[t]{5}{*}{ How can someone with cancer of the cervix be treated? } & Surgery & 94 & 23.3 \\
\hline & Specific drugs are given by a hospital & 92 & 22.8 \\
\hline & Radiotherapy & 92 & 22.8 \\
\hline & All & 19 & 4.7 \\
\hline & Don't know & 106 & 26.3 \\
\hline \multirow[t]{5}{*}{ Screening frequency } & Once a year & 240 & 59.6 \\
\hline & Every 3 years & 83 & 20.6 \\
\hline & Every 5 years & 30 & 7.4 \\
\hline & All & 5 & 1.2 \\
\hline & Don't know & 45 & 11.2 \\
\hline \multirow[t]{2}{*}{ Who should be screened? } & Women of $>25$ years & 195 & 48.4 \\
\hline & Prostitutes & 83 & 20.6 \\
\hline
\end{tabular}


Table 1 Knowledge towards cervical cancer and its screening at the University of Gondar, Ethiopia, April, 2018 ( $n=403)$ (Continued)

\begin{tabular}{|c|c|c|c|}
\hline Variables & Categories & Number & Percent (\%) \\
\hline & Elderly women & 30 & 7.4 \\
\hline & All & 51 & 12.7 \\
\hline & Don't know & 44 & 10.9 \\
\hline \multirow[t]{5}{*}{ Which screening method do you know? } & Papanicolau smear & 152 & 37.7 \\
\hline & Biopsy & 108 & 26.8 \\
\hline & Visual inspection with acetic acid & 39 & 9.7 \\
\hline & All & 35 & 8.7 \\
\hline & Don't know & 69 & 17.1 \\
\hline \multirow[t]{2}{*}{ Compute Knowledge of respondents } & Good & 239 & 59.3 \\
\hline & Poor & 164 & 40.7 \\
\hline
\end{tabular}

respondents, heard about cervical cancer and its screening from different information sources. Nearly one-third (32.8\%) of the respondents who heard about cervical cancer and its screening, got the information from their teachers. Less than one-third, 142 (35.2\%) of the respondents knew about the causative agent of cervical cancer. More than half of the respondents, $211(52 \%)$ knew about the sign and symptoms of cervical cancer, whereas 192(47.6\%) of the respondents didn't know. Among respondents who knew the sign and symptoms, $84(20.8 \%)$ of respondents said that Vaginal foul-smelling discharge is the symptom of the disease whereas, $83(20.6 \%)$ of the respondents reported that irregular vaginal bleeding is the symptom of the disease. However, one-third, 133 (33\%) of participants had no idea what factors raise the chance of getting cervical cancer, whereas one-quarter of participants 101 (25\%) reported that having multiple sexual partners is a risk factor for the disease. Most of the respondents, 296 (73.4\%), knew as early treatment can cure cervical cancer. Regarding knowledge on vulnerability for the Pap smear test, 195 (48.4\%) of the respondents pointed out that all women $>25$ years should get the Pap smear test (Table 1).

\section{Attitude towards cervical cancer}

More than two-thirds of the respondents 273(67.7\%) had a favorable attitude, whereas the remaining respondents $130(32.3 \%)$ had unfavorable attitude towards cervical cancer and its screening. The majority of the respondents, 361(89.6\%), had favorable attitude towards early detection. Only 229 (56.8\%) of the respondents responded that they have the chance of acquiring cervical cancer. More than one-quarter of the respondents 110 (27.3\%) thought that cervical carcinoma is transmitted from person to person. The majority of the respondents 348 (86.4\%) thought that screening helps to prevent cervical cancer (Table 2).

\section{Practices towards cervical cancer screening}

Most of the respondents 351(87.1\%), didn't have any sexual experience. Among respondents who had sexual experience, 36(69.2\%) had sexual intercourse at the age of $\geq 18$ years; whereas the smallest proportion of them $16(30.7 \%)$ had a history of sexual intercourse at the age of $<18$ years. Of all the respondents, only $2(0.5 \%)$ of them had been screened for cervical cancer at least once. With regard to the reasons why participants were not being screened, $211(52.4 \%)$ and $114(28.3 \%)$ of the respondents indicated that they never had experienced the illness and lack of information on the screening place. Among the total respondents, only $5(1.2 \%)$ of the respondents were vaccinated (Table 3 ).

\section{Discussion}

The findings of this study showed that, more than half $59.3 \%$ [with 95\% CI: $(54.3,64.0)$ ] of the respondents, had good knowledge, which is comparable with other studies done in Hawassa (56.8\%) [19] and Nigeria (63.0\%) [20]. In this study, $90 \%$ of the respondents have heard about cervical cancer from different sources, which is comparable with results reported in Nigeria (88.7\%) [20]. However, our finding is higher than a similar study conducted in Nigeria (72\%) [21], Hawassa (76.8\%) [19], Terkey (78.3) [22] and Wollega (54.4\%) [18]. The inconsistency may be due to the time variation. Of those, who had heard about cervical cancer, nearly one-third of the respondents $(32.8 \%)$, got this information from their teachers, $29.8 \%$ from mass media and $27 \%$ from health workers unlike to findings reported in Uganda, $70.2 \%$ of respondents got information from the radio [23]. The result is comparable with the study findings done in Wollega University in which mass-medias such as television and radio (36\%), brochures and posters (12.4\%), health workers $(7.3 \%)$ and teachers $(0.7 \%)$ were mentioned as a sources of information about cervical cancer [18].

This research finding showed that more than half of the respondents (52.4\%) knew about at least one possible 
Table 2 Attitudes towards cervical cancer at the University of Gondar, northwest Ethiopia, April, $2018(n=403)$

\begin{tabular}{|c|c|c|c|}
\hline Variables & Categories & Number & Percent (\%) \\
\hline \multirow[t]{5}{*}{ Do you think it is helpful to detect cervical cancer early? } & Strongly agree & 224 & 55.6 \\
\hline & Agree & 137 & 34 \\
\hline & Neutral & 32 & 7.9 \\
\hline & Disagree & 9 & 2.2 \\
\hline & Strongly disagree & 1 & 0.2 \\
\hline \multirow[t]{5}{*}{ Do you believe that you have the chance of getting Cervical Cancer? } & Strongly agree & 81 & 20.1 \\
\hline & Agree & 148 & 36.7 \\
\hline & Neutral & 48 & 11.9 \\
\hline & Disagree & 106 & 26.3 \\
\hline & Strongly disagree & 20 & 5.0 \\
\hline \multirow[t]{5}{*}{ Do you believe that getting Cervical Cancer is a serious for you? } & Strongly agree & 235 & 58.3 \\
\hline & Agree & 138 & 34.2 \\
\hline & Neutral & 16 & 4.0 \\
\hline & Disagree & 13 & 3.2 \\
\hline & Strongly disagree & 1 & 0.2 \\
\hline \multirow[t]{5}{*}{ Do you think that there are effective methods to reduce the risk of seriousness of cervical cancer? } & Strongly agree & 150 & 37.2 \\
\hline & Agree & 204 & 50.6 \\
\hline & Neutral & 33 & 8.2 \\
\hline & Disagree & 10 & 2.5 \\
\hline & Strongly disagree & 6 & 1.5 \\
\hline \multirow[t]{5}{*}{ Do you think Carcinoma of the cervix is the cause of death? } & Strongly agree & 157 & 39.0 \\
\hline & Agree & 157 & 39.0 \\
\hline & Neutral & 50 & 12.4 \\
\hline & Disagree & 34 & 8.4 \\
\hline & Strongly disagree & 5 & 1.2 \\
\hline \multirow[t]{5}{*}{ Do you think any women acquire cervical cancer? } & Strongly agree & 254 & 63 \\
\hline & Agree & 109 & 27 \\
\hline & Neutral & 24 & 6 \\
\hline & Disagree & 12 & 3 \\
\hline & Strongly disagree & 4 & 1 \\
\hline \multirow[t]{5}{*}{ Do you think carcinoma of the cervix can be treated? } & Strongly agree & 35 & 8.7 \\
\hline & Agree & 75 & 18.6 \\
\hline & Neutral & 94 & 23.3 \\
\hline & Disagree & 171 & 42.4 \\
\hline & Strongly disagree & 28 & 6.9 \\
\hline \multirow[t]{5}{*}{ Do you think screening helps in prevention of cervical cancer? } & Strongly agree & 186 & 46.2 \\
\hline & Agree & 162 & 40.2 \\
\hline & Neutral & 43 & 10.7 \\
\hline & Disagree & 9 & 2.2 \\
\hline & Strongly disagree & 3 & 0.74 \\
\hline \multirow[t]{4}{*}{ Willingness for screening } & Strongly agree & 100 & 24.8 \\
\hline & Agree & 185 & 45.9 \\
\hline & Neutral & 70 & 17.4 \\
\hline & Disagree & 39 & 9.7 \\
\hline
\end{tabular}


Table 2 Attitudes towards cervical cancer at the University of Gondar, northwest Ethiopia, April, 2018 ( $n=403$ ) (Continued)

\begin{tabular}{llll}
\hline Variables & Categories & Number & Percent (\%) \\
\hline Compute attitude towards Cervical Cancer & Strongly disagree & 9 & 2.2 \\
& Favorable & 273 & 67.7 \\
& Unfavorable & 130 & 32.3 \\
\hline
\end{tabular}

symptoms of cervical cancer such as vaginal foulsmelling discharge and irregular vaginal bleeding and Post coital bleeding. This finding is lower than other report done in Hawassa (67.9\%) [19]. Vaginal foul-smelling discharge and irregular vaginal bleeding is responded by one-fifth $(20.8 \%)$ and $20.6 \%$ of the respondents, respectively. A similar study was also done in Mizan Tepi University; Southern Ethiopia [17], 40.67 and $19.14 \%$ of the study participants were mentioned vaginal bleeding and foul-smelling vaginal discharge, respectively.

In the current finding, among respondents who knew about risk factors, a quarter (25.1\%) of participants reported that having multiple sexual partners is a risk factor for the disease. Among these risk factors having multiple sexual partners (25.1\%), Human papilloma virus (15.6\%) and early sexual intercourse (11.9\%) were mainly reported risk factors for cervical cancer. This result is similar to the previous study conducted in Hawassa [19] and Nigeria [24]. Among female University students, having several sexual partners was recognized as a major risk factor for cervical cancer in South Africa (62.5\%) [25] and Nigeria (28.2\%) [20]. On the other hand, avoidance of multiple sexual partners (25.1\%), avoidance of early sexual intercourse (16.99\%) and HPV vaccination (8.2\% were mentioned as preventive measures for cervical cancer which is supported by a study conducted in Wollega [18], Hawassa [19] and Tigray [26]. Nearly onethird (34.7\%) of the study participants did not know how can prevents cervical cancer which is higher than a report in South Africa (58.5\%) [3]. This discrepancy might be due to the time variation. Nearly three-fourth (73.4\%) of the respondents knew that cervical cancer can be treated and 23.3, 22.8 and $22.8 \%$ of the respondents mentioned surgery, drug and radiotherapy respectively as treatment option supported by a report in MizanTepi [17].

The attitude of the respondents towards cervical cancer and its screening was also assessed in the study.

Table 3 Practices towards cervical cancer screening among undergraduate female students at the University of Gondar, Ethiopia, April $2018(n=403)$

\begin{tabular}{|c|c|c|c|}
\hline Variables & Category & Number & Percent (\%) \\
\hline \multirow[t]{2}{*}{ Sexual experience } & Yes & 52 & 12.9 \\
\hline & No & 351 & 87.1 \\
\hline \multirow[t]{2}{*}{ Age at the first sex $(n=52)$} & $<18$ & 16 & 30.7 \\
\hline & $\geq 18$ & 36 & 69.2 \\
\hline \multirow[t]{2}{*}{ Number of sexual partners $(n=52)$} & Single & 33 & 63.5 \\
\hline & Multiple & 19 & 36.5 \\
\hline \multirow[t]{2}{*}{ Have you ever screened for cervical cancer } & Yes & 2 & 0.5 \\
\hline & No & 401 & 99.5 \\
\hline \multirow[t]{4}{*}{ Reason for not screened } & I am healthy & 211 & 52.4 \\
\hline & It may be painful & 55 & 13.6 \\
\hline & I feel shy & 23 & 5.7 \\
\hline & I'm not informed about screening place & 114 & 28.3 \\
\hline \multirow[t]{2}{*}{ Do you receive a cervical cancer vaccine? } & Yes & 5 & 1.2 \\
\hline & No & 398 & 98.8 \\
\hline \multirow[t]{2}{*}{ Have you had a Pap smear done before? } & Yes & 2 & 0.5 \\
\hline & No & 401 & 99.5 \\
\hline \multirow[t]{4}{*}{ If not had done, why? } & No interest & 3 & 0.7 \\
\hline & Partners will not allow & 18 & 4.5 \\
\hline & No time & 45 & 11.2 \\
\hline & Never heard of it & 337 & 83.6 \\
\hline
\end{tabular}


Higher proportion [67.7\% with 95\% CI: $(63.3,72.0)]$ of the respondents had a favorable attitude on cervical cancer and its screening which is higher than a report in Hawassa (55.3\% [19]. Recently the Ethiopian government is expanding the information regarding cervical cancer and its screening. Most of the respondents, $89.6 \%$ with 95\% CI: 86.6, 92.3 agreed that early detection of the disease is important for prevention of cervical cancer. In this study, more than half of $(56.8 \%)$ the respondents perceived that they can acquire the disease which is a little bit higher (49.28\%) than other report done in MizanTepi University, Ethiopia [17]. Less than three-fourths (72.7\%) of the respondents thought that cervical carcinoma can be transmitted from person to person. This finding is higher than the result reported in Mizan-Tepi, Ethiopia (39.72\%) [17].

Regarding to screening practice, only $0.5 \%$ of the respondents had done cervical cancer screening. In approximate to the current study, none of the study participants had undergone cervical cancer screening in Wollega prior to the study [18]. The report is lower than a report conducted in Nigeria (9\%) [20] and Tigray (17.2\%) [26] .The main reasons mentioned for unscreened were feeling healthy, shy during vaginal examination and lack of information where the screening was given.

Among the total respondents, only $1.2 \%$ had vaccinated. The result is lower than a study conducted in Malaysia medical and pharmacy students, $3.6 \%$ of the study participants took the HPV vaccine [27]. This evidence showed that special attention should be given to the prevention of the disease through early vaccination. This might be because of the late starting of HPV vaccination in developing countries particularly, Ethiopia.

\section{Limitation}

The results about attitude and practices towards cervical cancer screening were based on self-reports of participants, which may answer due to social desirability that may result in over or under estimates. The other limitation can be this study was not including all University campus students in the study area. It is only descriptive study. Due to lack of sufficient literatures, some comparisons were made with different population.

\section{Conclusion}

Despite the University female students had apparently good knowledge and favorable attitude, their screening practice on cervical cancer was very low. Thus, the health sectors and the gender streaming office of the university need to mobilize students to strengthen the uptake the cervical cancer screening practice.

\section{Abbreviations}

Cl: Confidence Interval; HPV: Human Papilloma Virus; KAP: Knowledge Attitude and Practice; SD: Standard Deviation; SPSS: Statistical Package for Social Science

\section{Acknowledgments}

The authors would like to acknowledge the University of Gondar, College of Medicine, and Health Sciences, School of Biomedical and Laboratory sciences for their logistic and material support. The authors would also like to thank study participants and facilitators for data collection.

\section{Authors' contributions}

AG involved in the collection of data, analysis and interpretation of data and in writing the manuscript. BT and TB involved in proposal writing, data analysis and interpretation of results. All authors have read and approved the final manuscript.

\section{Funding}

The source of funding for this research was the authors.

\section{Availability of data and materials}

The datasets used and/or analyzed during the current study are available from the corresponding author on reasonable request.

\section{Declarations}

Ethics approval and consent to participate

The study protocol was reviewed from Research Ethical Committee in School of Biomedical and Laboratory Sciences, University of Gondar. The study was carried out after obtaining the ethical clearance. Since the age of all the study participants were 18 and above in years, written informed consent was obtained from all study participants. Confidentiality was secured by using anonymous data collection tools and the data analysis was not also included any identification of the study participants. In addition, the participants were informed on they have a full right to withdraw from the study at any time if they have any inconvenience. We can confirm that all methods were performed in accordance with the relevant guidelines and regulations of research ethics.

\section{Consent for publication}

Not applicable.

\section{Competing interests}

The authors declare that they have no competing interests.

\section{Author details}

'Department of Medical Microbiology, School of Biomedical and Laboratory Science, College of Medicine and Health Sciences, University of Gondar, 196 Gondar, Ethiopia. ${ }^{2}$ St. Paul's Hospital Millennium Medical College, Addis Ababa, Ethiopia.

Received: 22 November 2020 Accepted: 12 April 2021

Published online: 23 April 2021

\section{References}

1. Tekle T, Wolka E, Nega B, Kumma WP, Koyira MM. Knowledge, attitude and practice towards cervical cancer screening among women and associated factors in hospitals of Wolaita Zone, Southern Ethiopia. Cancer Manag Res. 2020;2020(12):993-1005.

2. Endalew DA, Moti D, Mohammed N, Redi S, Wassihun AB. Knowledge and practice of cervical cancer screening and associated factors among reproductive age group women in districts of Gurage zone, Southern Ethiopia. A cross-sectional study. PloS one. 2020;15(9):e0238869.

3. Hoque $\mathrm{E}$, Hoque M. Knowledge and attitude towards cervical cancer among female university students in South Africa. South Afr J Epidemiol Infect. 2009;24(1):21-4. https://doi.org/10.1080/10158782.2009.11441335.

4. Liu Y, Ang Q, Wu H, Xu J, Chen D, Zhao H, et al. Prevalence of human papillomavirus genotypes and precancerous cervical lesions in a screening population in Beijing, China: analysis of results from China's top 3 hospital, 2009-2019. Virol J. 2020;17(1):1-10. 
5. Human Papillomavirus and Related Diseases Report World Version posted at www.hpvcentre.net on 17 June 2019. https://www.hpvcentre.net/statistics/ reports/XWX.pdf. Accessed 12 Nov 2020.

6. Igwilo A, Igwilo $U$, Hassan F, Idanwekhai M, Igbinomwanhia O, Popoola A The knowledge, attitude and practice of the prevention of cancer of the cervix in Okada community. Asian J Med Sci. 2012;4(3):95-8.

7. Oche M, Kaoje A, Gana G, Ango J. Cancer of the cervix and cervical screening: current knowledge, attitude and practices of female health workers in Sokoto, Nigeria. Int J Med Med Sci. 2013;5(4):184-90.

8. Adoch W, Garimoi CO, Scott SE, Okeny GG, Moodley J, Komakech H, et al. Knowledge of cervical cancer risk factors and symptoms among women in a refugee settlement: a cross-sectional study in northern Uganda. Confl Heal. 2020;14(1):1-9.

9. Dalla V, Panagiotopoulou E-K, Deltsidou A, Kalogeropoulou M, Kostagiolas P, Niakas D, et al. Level of awareness regarding cervical cancer among female Syrian refugees in Greece. J Cancer Educ. 2020;35:1-11.

10. Wright K, Aiyedehin O, Akinyinka M, Ilozumba O. Cervical cancer: community perception and preventive practices in an urban neighborhood of Lagos (Nigeria). ISRN Prev Med. 2014;2014:1-9.

11. Ruddies F, Gizaw M, Teka B, Thies S, Wienke A, Kaufmann AM, et al. Cervical cancer screening in rural Ethiopia: a cross-sectional knowledge, attitude and practice study. BMC Cancer. 2020;20(1):1-10.

12. WHO. Human papillomavirus (HPV) and cervical cancer. WHO fact sheet. 2020. Available at: https://www.who.int/news-room/factsheets/detail/huma n-papillomavirus-(hpv)-and-cervical-cancer.

13. Ibrahim U. Assessment of cervical Cancer knowledge, perception and Preven-tion attitude among female students of reproductive age (16-49) in four tertiary institution within Bauchi Metropolis. Int J Adv Res Tech. 2014; 3(11):1-6.

14. $\mathrm{FMOH}$. National Strategic Action Plan (NSAP) for prevention \& control of non communicable diseases in Ethiopia from 2014-2016. Available at https://www.iccpportal.org/system/files/plans/ETH_B3_National\%20Stra tegic\%20Action\%20Plan\%20\%28NSAP\%29\%20for\%20Prevention\%20and\%2 OControl\%20of\%20Non-Communicable\%20Diseases\%20-\%20Final.pdf.

15. Begoinn M, Mathewos A, Aynalem A, Wondemagegnehu T, Moelle U, Gizaw M, et al. Cervical cancer in Ethiopia-predictors of advanced stage and prolonged time to diagnosis. Infect Agents Cancer. 2019; 14(1):1-7.

16. Gultie A, Sahile S, Subramanian C. Assessment of fruit management in Gondar town market of Northwestern Ethiopia. GJBAHS. 2013;2(4): 4-8.

17. Mulatu K, Motma A, Seid M, Tadesse M. Assessment of Knowledge, Attitude and Practice on Cervical Cancer Screening among Female Students of MizanTepi University, Ethiopia 2016. Cancer Biol Ther Oncol. 2017;1:1.

18. Tilahun T, Tulu T, Dechasa W. Knowledge, attitude and practice of cervical cancer screening and associated factors amongst female students at Wollega University, western Ethiopia. BMC Res Notes. 2019; 12(1):1-5

19. Shimeles T. Knowledge, attitude, practice of cervical cancer screening and its associated factors among female students in Hawassa University college of medicine and health science hawassa Ethiopia: Addis Ababa University; 2015.

20. Isara A, Awunor N, Erameh L, Enuanwa E, Enofe I. Knowledge and practice of cervical cancer screening among female medical students of the University of Benin, Benin City Nigeria. Afr J Online (AJOL). 2013; 12(1).

21. Owoeye I, Ibrahim I. Knowledge and attitude towards cervical cancer screening among female students and staff in a tertiary institution in the Niger Delta. Int J Med Biomed Res. 2013;2(1):48-56. https://doi.org/10.141 94/ijmbr.219.

22. Borlu A, Gunay O, Balci E, Sagiroglu M. Knowledge and attitudes of medical and non-medical Turkish university students about cervical cancer and HPV vaccination. Asian Pac J Cancer Prev. 2016;17(1):299-303. https://doi.org/10. 7314/APJCP.2016.17.1.299.

23. Mukama T, Ndejjo R, Musabyimana A, Halage AA, Musoke D. Women's knowledge and attitudes towards cervical cancer prevention. BMC Womens Health. 2017;17(1):9. https://doi.org/10.1186/s12905-017-0365-3.

24. Akujobi CN, Ikechebelu Jl, Onunkwo I. Knowledge, attitude and practice of screening for cervical canceramong female students ofa tertiary institution in South Eastern Nigeria. Niger J Clin Pract 2008;11(3):216-9.
25. Hoque ME, Ghuman S, van Hal G. Human papillomavirus vaccination acceptability among female university studentsin South Africa. Asian Pac J Cancer Prev. 2013;14:4865-9.

26. Gebregziabher D, Berhanie E, Birhanu T, Tesfamariam K. Correlates of cervical cancer screening uptake among female under graduate students of Aksum University, College of Health Sciences, Tigray, Ethiopia. BMC Res Notes. 2019:12:520.

27. Rashwan HH, Saat NZNM, Manan DNA. Knowledge, attitude and practice of malaysian medical and pharmacy students towards human papillomavirus vaccination. Asian Pac J Cancer Prev. 2012;13(5):2279-83. https://doi.org/10. 7314/APJCP.2012.13.5.2279.

\section{Publisher's Note}

Springer Nature remains neutral with regard to jurisdictional claims in published maps and institutional affiliations.
Ready to submit your research? Choose BMC and benefit from:

- fast, convenient online submission

- thorough peer review by experienced researchers in your field

- rapid publication on acceptance

- support for research data, including large and complex data types

- gold Open Access which fosters wider collaboration and increased citations

- maximum visibility for your research: over $100 \mathrm{M}$ website views per year

At BMC, research is always in progress.

Learn more biomedcentral.com/submissions 